University of Montana

ScholarWorks at University of Montana

$5-1987$

\title{
A Description of Mixed-Species Insectivorous Bird Flocks in Western Mexico
}

Richard L. Hutto

University of Montana - Missoula, hutto@mso.umt.edu

Follow this and additional works at: https://scholarworks.umt.edu/biosci_pubs

Part of the Biology Commons

Let us know how access to this document benefits you.

\section{Recommended Citation}

Hutto, Richard L., "A Description of Mixed-Species Insectivorous Bird Flocks in Western Mexico" (1987). Biological Sciences Faculty Publications. 274.

https://scholarworks.umt.edu/biosci_pubs/274

This Article is brought to you for free and open access by the Biological Sciences at ScholarWorks at University of Montana. It has been accepted for inclusion in Biological Sciences Faculty Publications by an authorized administrator of ScholarWorks at University of Montana. For more information, please contact scholarworks@mso.umt.edu. 


\title{
A DESCRIPTION OF MIXED-SPECIES INSECTIVOROUS BIRD FLOCKS IN WESTERN MEXICO ${ }^{1}$
}

\author{
RichaRd L. HUTTO \\ Department of Zoology, University of Montana, Missoula, MT 59812
}

\begin{abstract}
Insectivorous bird flocks were observed in all types of forested habitats during the nonbreeding season in western Mexico. The species composition of flocks changed markedly and predictably among five categories of habitat type. The average number of species per flock in lowland habitats was 4.7 , while a mean of 18.6 species participated in highland flocks, ranking the latter among the most species-rich flocks in the world. The mean proportion of the local insectivorous species that participated in mixed-species flocks was significantly greater in the highlands $(61.3 \%)$ than in the lowlands $(24.6 \%)$. About half of the flock participants in both undisturbed lowland and highland habitats were north temperate migrants, ranking west Mexican flocks among the most migrant-rich in the world as well. In highland flocks, the maximum number of individuals per attendant species was generally two to three, but there were often six to twelve individuals belonging to each of several nuclear species. The lowland deciduous forest flocks seemed to lack nuclear species.
\end{abstract}

Key words: Mixed-species flocks; insectivorous birds; Mexico; migratory birds; pine-oak woodlands; tropical deciduous forests.

\section{INTRODUCTION}

Mixed-species insectivorous bird flocks have been described from temperate and tropical areas worldwide (Rand 1954), and are known to occur in practically every habitat type (Powell 1985). Although mixed-species flocks are quite common in north temperate regions during the nonbreeding season (Morse 1970), they generally reach their greatest sizes and species diversities in tropical regions (Moynihan 1962, Powell 1985). A noteworthy exception to this temperate-totropical region trend in flock complexity involves the highland mixed-species flocks of western Mexico. Except for a brief note on the species composition of a few flocks from Oaxaca (Short 1961), there is no published information on the flocks of Mexico. In the present paper, I (1) describe the relationship between flock composition and habitat type from locations throughout western Mexico in winter, (2) describe the degree of flock participation by wintering species in both highland and lowland habitats, and (3) compare the organization of Mexican flocks to that of flocks from elsewhere in the world.

\section{STUDY SITES AND METHODS}

\section{STUDY SITES}

I spent January through February, and July of 1975 and 1976 surveying the composition of

\footnotetext{
'Received 9 December 1985. Final acceptance 11 December 1986.
}

mixed-species flocks in 26 sites (Appendix I) that were distributed among various habitats throughout western Mexico. The habitat types that I surveyed can be roughly classified (after Pesman 1962) as belonging to either lowland (tropical deciduous and tropical evergreen) or highland (oak, pine-oak, and boreal) forests. In addition, I visited one lowland and one highland site for more extended periods either to conduct more complete censuses so that the level of participation by winter residents could be estimated, or to gather information about the daily pattern of flocking behavior. These sites included the pine-oak woodland at the La Michilia International Biosphere Reserve, Durango ( 7 to 20 January $1984 ; 23^{\circ} 30^{\prime} \mathrm{N}, 104^{\circ} 15^{\prime} \mathrm{W}$ ) and the tropical deciduous forest at the Estación de Biologia Chamela, Jalisco (21 to 28 February, 7 November to 5 December $1984 ; 19^{\circ} 30^{\prime} \mathrm{N}, 105^{\circ} 03^{\prime} \mathrm{W}$ ).

\section{FLOCK SURVEYS}

I defined a mixed-species flock as a group of two or more species occurring within $25 \mathrm{~m}$ of one another and moving in concert. These were not chance aggregations of individuals - they were foraging groups of individuals that maintained group cohesion. I typically observed a single flock on a given date within a survey site (Appendix I) for 1 to $2 \mathrm{hr}$ to determine its species composition, but I never moved more than about 200 $m$ during this period because I wanted to measure the number of species that were participat- 
ing at the same time. This constraint therefore minimized species accumulations that might have accrued because of species turnover as the flock progressed through space (Austin and Smith 1972, Powell 1979, Gradwohl and Greenberg 1980). Gibb (1960) noted that it generally took an average of about a minute per individual to be fairly confident that all the species within a flock had been identified, and I concur. On occasion, it was difficult to distinguish between a flock participant and a nonparticipant. In such instances, the decision to include or exclude an individual as a participant was based on observation of that individual for several minutes, until I was able to discern whether it was moving in response to, or at least in concert with, the movement of others. This survey of flock compositions which included a broad range of geography and habitat types was, therefore, bought at a cost in terms of information on variance in flock composition within a site. Nonetheless, by grouping the flocks into habitat categories, I was able to investigate the degree to which habitat types and flock compositions were interrelated through cluster analysis. The clustering procedure involved use of the correlation coefficient as a measure of similarity in flock composition among sites and the average linkage algorithm (Hartigan 1981). I have used English names of the bird species throughout; scientific nomenclature is provided in Appendix II.

\section{THE LEVEL OF PARTICIPATION IN FLOCKS}

I walked a straight path through the forest until I encountered an individual bird and recorded whether that individual was participating in a mixed-species flock (as defined above). I then continued on until the next individual was encountered. No individual birds were skipped or ignored, so my estimate of the proportion of time that a given species participated in flocks was not biased by the conscious selection or avoidance of particular species.

\section{RESULTS AND DISCUSSION}

\section{HABITAT DISTRIBUTION AND SPECIES COMPOSITION OF FLOCKS}

Just as Moynihan (1979) and Powell (1980) have described for other geographic locations, mixedspecies insectivorous bird flocks were ubiquitous in western Mexico. During the winter months and in July, I found such flocks in nearly every habitat type (save deserts and grasslands) from

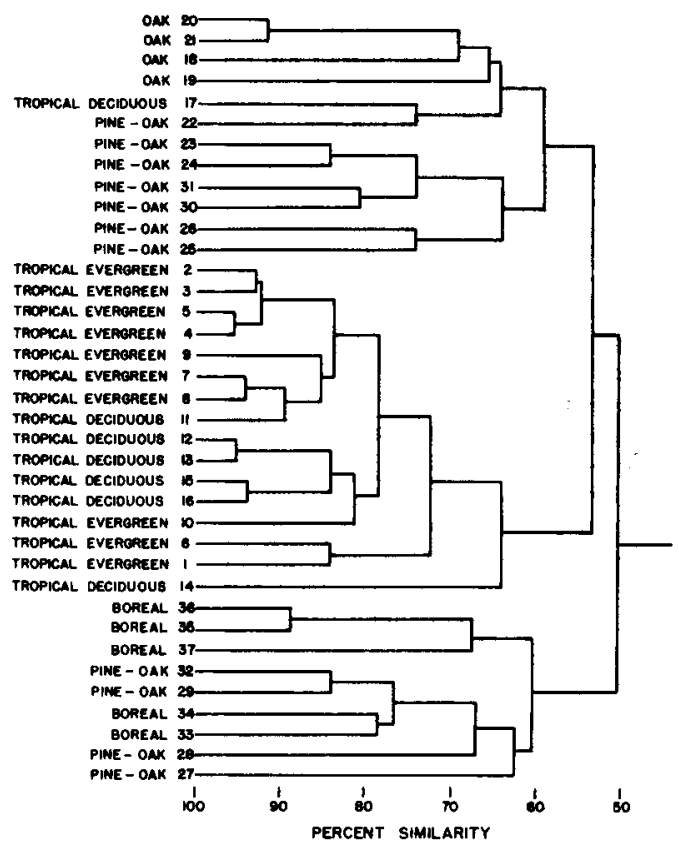

FIGURE 1. Average linkage cluster diagram of west Mexican bird flocks based on the similarity of their bird species compositions. Geographic location of each flock (coded numerically) is given in Appendix I.

sea level to the highest forested elevations (Table 1). The species composition of these flocks varied markedly among sites, but there was a clear association between flock composition and habitat type (Fig. 1). Even though flock compositions for a site were based on the identification of members of a single flock, the cluster analysis shows that the within-habitat variance in flock composition was generally much less than the between-habitat variance in flock composition. The least species-rich flocks were observed in the lowland tropical deciduous forests (mean $=4.7$ species; $n=7$ ), while the most diverse flocks were observed in the pine-oak woodlands (mean = 18.6 species; $n=11$ ). The mean values reported here for species richness do not represent the pool of species that might participate in such flocks, they are the values based on numbers of species actually observed foraging together within a restricted space and a limited period of time (see Methods). The diversity of west Mexican flocks is, therefore, noteworthy in light of the fact that the average number of species found to forage simultaneously in mixed-species flocks is generally less than 10, anywhere in the world (Moyn- 
TABLE 1. The composition of mixed-species insectivorous bird flocks over a series of five habitat types. Each column represents presence $(+)$ /absence (blank) information as determined from following a single flock for an extended (1 to $2 \mathrm{hr}$ ) period. Data were taken from western Mexican sites in winter (see Appendix I for key to geographic locations of flocks).

\begin{tabular}{|c|c|c|c|c|c|c|c|c|c|c|c|c|c|c|c|c|c|}
\hline \multirow[b]{3}{*}{ Species } & \multicolumn{17}{|c|}{ Flock number } \\
\hline & \multicolumn{10}{|c|}{ Tropical evergreen forest edge } & \multicolumn{7}{|c|}{ Tropical deciduous forest } \\
\hline & 1 & 2 & 3 & 4 & 5 & 6 & 7 & 8 & 9 & 10 & 11 & 12 & 13 & 14 & 15 & 16 & 17 \\
\hline Tropical Parula & + & + & + & + & + & + & + & + & & & & & & & & & \\
\hline Blue-gray Gnatcatcher & + & + & + & + & + & + & + & + & + & + & + & + & + & + & & & + \\
\hline Wilson's Warbler & + & + & + & + & + & + & + & + & & + & + & + & + & & + & + & \\
\hline Nashville Warbler & & + & + & + & + & & + & + & + & + & & + & + & + & + & + & \\
\hline Orange-crowned Warbler & & + & & + & + & & + & + & + & + & + & + & + & & + & + & \\
\hline Yellow-rumped Warbler & & + & + & + & + & & & + & + & & + & & & & & & \\
\hline Warbling Vireo & & & & + & + & + & + & + & + & & + & + & + & & & & + \\
\hline $\begin{array}{l}\text { Black-throated Gray War- } \\
\text { bler }\end{array}$ & & & & & & + & + & + & & & + & & & & & + & \\
\hline Solitary Vireo & & & & & & & + & + & + & & + & & & & & & + \\
\hline Black-and-white Warbler & & & & & & & & $t$ & & + & & & & & & & + \\
\hline Virginia's Warbler & & & & & & & & & & & & & & + & + & & \\
\hline Ash-throated Flycatcher & & & & & & & & & & & & & & & + & & \\
\hline Hepatic Tanager & & & & & & & & & & & & & & & & & \\
\hline Rufous-capped Warbler & & & & & & & & & & & & & & & & & \\
\hline Painted Redstart & & & & & & & & & & & & & & & & & \\
\hline Tufted Flycatcher & & & & & & & & & & & & & & & & & \\
\hline $\begin{array}{l}\text { White-striped Wood- } \\
\text { creeper }\end{array}$ & & & & & & & & & & & & & & & & & \\
\hline Ladder-backed Wood- & & & & & & & & & & & & & & & & & \\
\hline pecker & & & & & & & & & & & & & & & & & \\
\hline White-breasted Nuthatch & & & & & & & & & & & & & & & & & \\
\hline Bridled Titmouse & & & & & & & & & & & & & & & & & \\
\hline Greater Pewee & & & & & & & & & & & & & & & & & \\
\hline Ruby-crowned Kinglet & & & & & & & & & & & & & & & & & \\
\hline Hutton's Vireo & & & & & & & & & & & & & & & & & \\
\hline Slate-throated Redstart & & & & & & & & & & & & & & & & & \\
\hline Townsend's Warbler & & & & & & & & & & & & & & & & & \\
\hline Bushtit & & & & & & & & & & & & & & & & & \\
\hline Empidonax sp. & & & & & & & & & & & & & & & & & \\
\hline Spotted Wren & & & & & & & & & & & & & & & & & \\
\hline Olive Warbler & & & & & & & & & & & & & & & & & \\
\hline Crescent-chested Warbler & & & & & & & & & & & & & & & & & \\
\hline Hermit Warbler & & & & & & & & & & & & & & & & & \\
\hline Grace's Warbler & & & & & & & & & & & & & & & & & \\
\hline Brown Creeper & & & & & & & & & & & & & & & & & \\
\hline Mexican Chickadee & & & & & & & & & & & & & & & & & \\
\hline Red-headed Tanager & & & & & & & & & & & & & & & & & \\
\hline Red-faced Warbler & & & & & & & & & & & & & & & & & \\
\hline Strickland's Woodpecker & & & & & & & & & & & & & & & & & \\
\hline Golden-browed Warbler & & & & & & & & & & & & & & & & & \\
\hline Gray-barred Wren & & & & & & & & & & & & & & & & & \\
\hline Red Warbler & & & & & & & & & & & & & & & & & \\
\hline Golden-crowned Kinglet & & & & & & & & & & & & & & & & & \\
\hline
\end{tabular}

ihan 1962, 1979; Powell 1985). West Mexican flocks are clearly extreme in the number of species that participate, especially in the case of pineoak woodland flocks, where woodpeckers, woodcreepers, flycatchers, chickadees, titmice, bushtits, nuthatches, creepers, wrens, kinglets, gnatcatchers, vireos, warblers, and tanagers all participate simultaneously (Table 1).
The highland flocks are also unique in the level of participation by the pool of available species. Using data from Hutto (1980:table 1), the mean proportion of insectivorous species within a given highland site that participated in mixed-species flocks $(61.3 \%, n=12)$ was significantly $(U=168$, $P<0.001)$ greater than the mean proportion that participated in lowland flocks $(24.6 \%, n=14)$. 
TABLE 1. Extended.

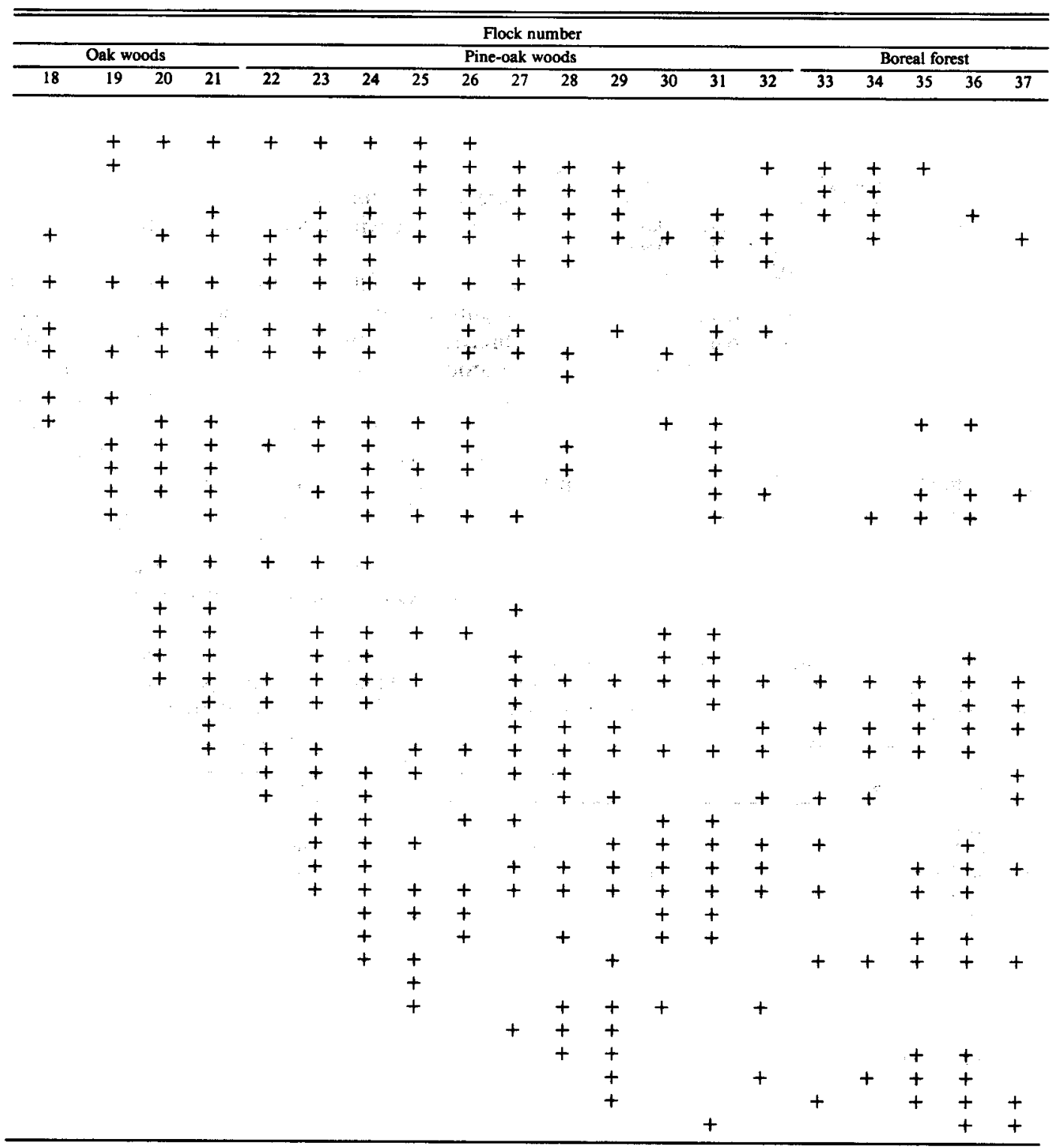

In fact, no fewer than $50 \%$ of all insectivorous bird species participated in the highland habitats; this normally included at least $95 \%$ of the smaller, warbler-sized insectivorous bird species. Nonparticipant species generally included those that foraged predominantly on the ground or in dense understory vegetation.

Moreover, I used focal individual sampling in the pine-oak woodlands at La Michilia, and found that, given a landbird of any species (not just insectivores), the probability that another bird would be found within $25 \mathrm{~m}$ and moving in concert with the focal bird was 0.93 (Table 2). While it may be true that such a method biases observations toward more easily detected (flocking) individuals, this level of participation in mixed- 
TABLE 2. For focal birds from each of five foraging guilds, values represent the proportion of $n$ observations for which at least one other individual was found in association with a focal individual at the time the focal bird was encountered, P (group). Data are further subdivided into the probability that there was an associate of another species, $P(\mathrm{MSF})$ and the probability that there was another individual of the same species, $P$ (conspecific).

\begin{tabular}{lrrrrr}
\hline \hline \multicolumn{1}{c}{ Guild } & Species & \multicolumn{1}{c}{$n$} & $\begin{array}{c}\mathbf{P} \\
\text { (group) }\end{array}$ & $\begin{array}{c}P \\
\text { (MSF) }\end{array}$ & $\begin{array}{c}P \\
\text { (conspe- } \\
\text { cific) }\end{array}$ \\
\hline Nectarivores & 3 & 21 & 0.38 & 0.33 & 0.19 \\
Insectivores & 26 & 301 & 0.96 & 0.95 & 0.58 \\
Frugivores & 8 & 102 & 0.89 & 0.83 & 0.72 \\
Omnivores & 2 & 30 & 1.00 & 0.93 & 0.80 \\
Granivores & 7 & 95 & 0.95 & 0.62 & 0.87 \\
All species & 46 & 549 & 0.93 & 0.85 & 0.65 \\
\hline
\end{tabular}

species flocks by the pool of available landbird species is unusually high relative to other published reports based on the same method, which indicate that most nonnuclear species participate less than $50 \%$ of the time (Moynihan 1962, Her- rera 1979, Bell 1980). On the surface, these results may seem inconsistent with the species lists in Table 1 because it appears as if the number of participant species at a given site within a particular habitat is far less than the pool of available species within that habitat. These differences are more a reflection of differences in the numbers of bird species among geographic locations, however, rather than a reflection of offand-on participation by the species in any one site. Only nectarivorous species were unlikely to be observed with associates at La Michilia (Table 2).

Analysis of flock compositions from six of the highland locations immediately following the breeding season (July) before the return of $\mathrm{mi}$ gratory species revealed that an average of $53 \%$ of the winter participant species were north temperate migrants; they were absent in July (compare Tables 1 and 3). Moreover, this estimate is conservative because the populations of some "resident" species (determined as such because of their presence in July-Warbling Vireo, Solitary Vireo, Painted Redstart, Ruby-crowned Kinglet, Olive Warbler, and Grace's Warbler),

TABLE 3. The composition of mixed-species insectivorous bird flocks from six highland sites that were visited in July, before the arrival of migrants. Presence $(+)$ or absence (blank) of a given bird species was determined by following a single flock for 1 to $2 \mathrm{hr}$. Geographic locations of bird flocks are given in Appendix I.

\begin{tabular}{|c|c|c|c|c|c|c|}
\hline \multirow[b]{2}{*}{ Species } & \multicolumn{6}{|c|}{ Flock number } \\
\hline & 38 & 39 & 40 & 41 & 42 & 43 \\
\hline Warbling Vireo & & & + & + & & \\
\hline Solitary Vireo & + & + & + & + & + & \\
\hline Hepatic Tanager & + & + & + & + & & \\
\hline Rufous-capped Warbler & & + & + & + & & \\
\hline Painted Redstart & + & & + & + & + & \\
\hline Tufted Flycatcher & + & & & + & & + \\
\hline White-striped Woodcreeper & & & & + & & + \\
\hline Ladder-backed Woodpecker & + & & & & & \\
\hline White-breasted Nuthatch & & & + & & & \\
\hline Bridled Titmouse & + & & + & + & & \\
\hline Ruby-crowned Kinglet & & + & + & + & & + \\
\hline Hutton's Vireo & & + & + & & & \\
\hline Slate-throated Redstart & & & + & & + & + \\
\hline Bushtit & + & & + & & + & \\
\hline Empidonax sp. & & + & & + & & \\
\hline Spotted Wren & & + & + & + & + & \\
\hline Olive Warbler & & & + & + & & + \\
\hline Crescent-chested Warbler & & + & + & + & & + \\
\hline Grace's Warbler & & $\therefore$ & & + & & \\
\hline Brown Creeper & & & + & + & & + \\
\hline Mexican Chickadee & & & + & & $\cdot$ & + \\
\hline Golden-browed Warbler & & & & & + & \\
\hline Gray-barred Wren & & & & & & $\therefore t$ \\
\hline Red Warbler & & & & & + & + \\
\hline Golden-crowned Kinglet & & & & & & + \\
\hline
\end{tabular}


are migratory in the northern parts of their breeding ranges. These species may, therefore, have been composed of both migrant and resident individuals in winter.

In the lowland forests in July, I did not detect mixed-species flocks in three sites that were revisited (sites of flocks 1, 11, and 16) because virtually all of the insectivorous bird species that were observed to participate in flocks there in winter were migrants ( 10 of the 12 lowland species listed in Table 1). It would be unsafe to conclude that the lowland flocks are predominated by migrants, however, because many of these lowland sites were disturbed, and there is evidence that migrants are uncommonly abundant relative to residents in the disturbed lowland forests of western Mexico (Hutto 1980). In November 1984, I revisited the undisturbed tropical deciduous forest at Chamela, Jalisco (site of flock 17), and data from detailed observations of flocks there indicated that $25 \%$ of the 60 resident species and $55 \%$ of the 20 migratory species that were detected at the site in winter participated in mixedspecies insectivorous bird flocks. Considering insectivorous species only, this included $50 \%$ of the 30 resident species and $55 \%$ of the $18 \mathrm{mi}$ gratory species. The average flock size at Chamela was $7.7(n=57)$ and long distance migrants comprised at least eight, and as many as 13 of the 20 species that commonly participated ( 40 to $65 \%$ ). Thus, in undisturbed lowland or highland habitats, about half of the individuals in any given flock are migrants. The proportions of migratory species in mixed-species flocks reported elsewhere in the literature are less than $10 \%$, on average (Davis 1946, Moynihan 1962, Croxall 1976, Greig-Smith 1978, Herrera 1979, Bell 1980), although Cuban (Eaton 1953) and Colombian (Chipley 1977) flocks have been reported to have greater than $50 \%$ migrants.

The unusually large, species-rich, and migrantrich flocks in the west Mexican highlands may be primarily a consequence of the fact that the highlands experience a tremendous influx of northern temperate migrants which accumulate there, rather than continuing farther south into Central and South America. Reasons for such an accumulation of migrants are probably associated with the contiguity of what are essentially temperate habitats, and with the benefits accrued by using the same habitat year-round (Hutto 1985). Whatever the reason, this phenomenon of large and diverse flocks in western Mexico is also enigmatic because the time period during which bird diversity is greatest coincides with the time during which food resources are apparently at their lowest levels of the year (Hutto 1980:193). This finding would seem to run counter to the conventional wisdom that diversity and resource productivity are directly related (MacArthur 1972, Brown 1973, Cody 1974). Migratory species have often been said to arrive in time to exploit a flush of food that becomes available only during the winter residence period (Willis 1966, Karr 1976, Herrera 1978, Sinclair 1978, Feinsinger 1980, Hutto 1980, DesGranges and Grant 1980). This is apparently not the case for insectivores that winter in the undisturbed lowland and highland habitats of western Mexico because these highly integrated and cooperative flocking units occur at a time period during which the seasonally dry lowland deciduous forests lose their leaves, and the temperate-like highland habitats experience the winter cold season. Because an obvious flush in productivity does not coincide with the arrival of migrants, this leaves open the question of whether migrants and residents act to limit one another's populations.

\section{ORGANIZATION OF FLOCKS IN WESTERN MEXICO}

A typical daily cycle begins with the formation of a large, cohesive flock. Flocks are apparently not fully formed and moving as a single unit until an hour or so after sunrise. It is as if it takes a while for individuals to "find" one another. After 08:00 or so the flocks are as tight as they will get throughout the day. This is similar to the formation of highland flocks in Panama as described by Buskirk et al. (1972) and highland flocks in Kashmir (MacDonald and Henderson 1977). A typical flock will not move rapidly ( $<10$ $\mathrm{cm} / \mathrm{sec}$ ) and will be a rather loose association encompassing an area of 1,000 to $2,500 \mathrm{~m}^{2}$, depending on flock size. Foraging activity remains high throughout the day in the highlands, but drops off in more typical insectivore fashion (Hutto 1981) in the lowlands.

In the undisturbed lowlands, I never observed monospecific foraging groups of insectivores, and nuclear species - sensu Moynihan (1962)-were apparently absent. In contrast, highland flocks often consisted of a core of passive nuclear species, as evidenced by the fact that individuals of such species could occasionally be observed foraging in monospecific groups (never as solitary indi- 


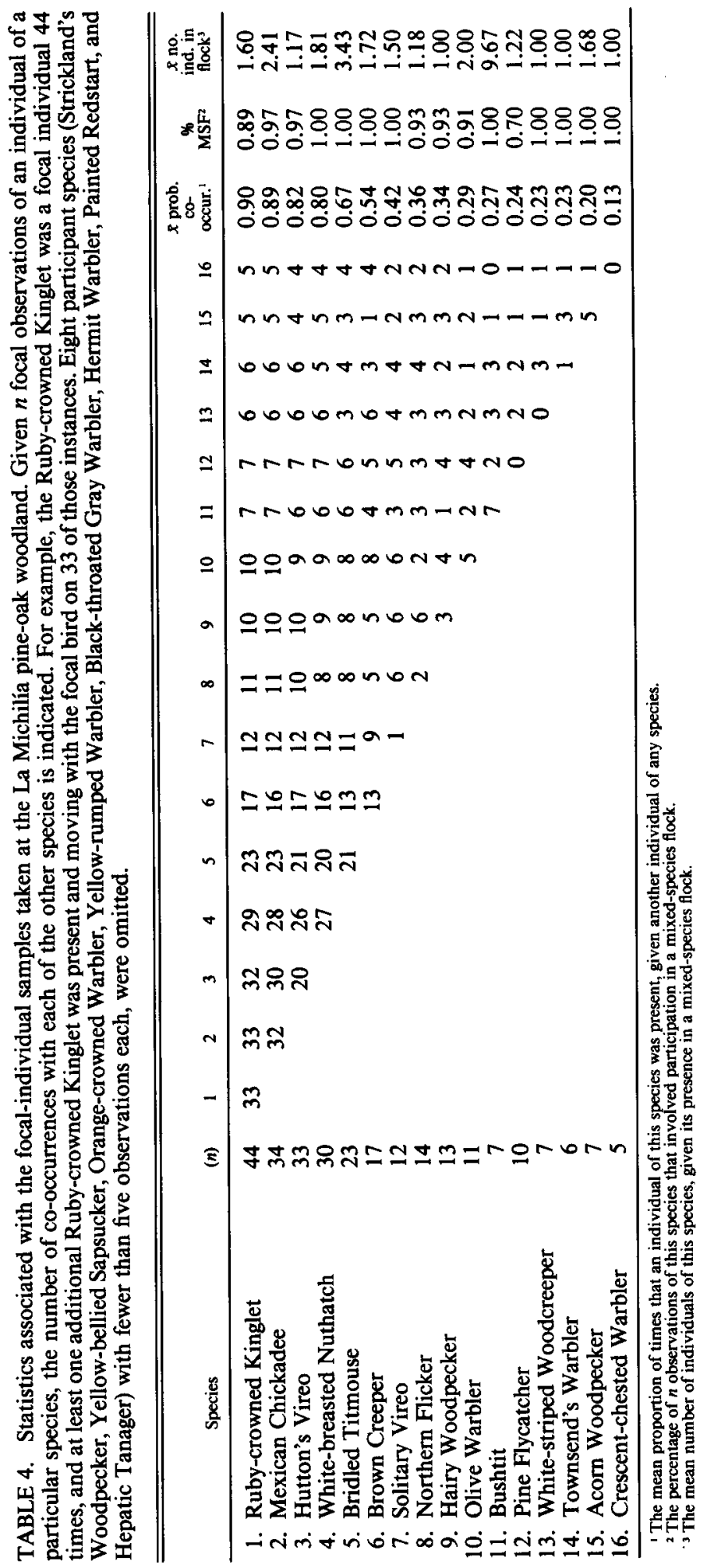


viduals) and, when they were part of a mixedspecies flock, were joined and followed more often than they joined or followed others. The nuclear species generally included Bridled Titmice, and/ or Mexican Chickadees, which is similar to the situation found in the pine-oak woodland flocks of southern Arizona, as described by Austin and Smith (1972). Given a flock, one or more of these species was most always present (Table 4). Each of these species, plus Bushtits, consisted of a half dozen or more individuals, while all the remaining attendant species consisted of no more than two or three individuals. The mean number of individuals per species for each of 21 attendant species was less than 2.0 , while it was greater than 2.0 for the Bushtit, Mexican Chickadee, and Bridled Titmouse (Table 4).

The flock composition data taken from La Michilia were somewhat atypical because this site was located far enough north to be only marginally within the area of concentration of wintering migrants. In particular, while the low probabilities of coexistence with conspecifics (as shown by values in the diagonal of Table 4) accurately reflect the situation at La Michilia, these values would be considerably higher for most attendant species if calculated on the basis of data taken from farther south, where most attendant species are only rarely seen solitarily. In most locations, the attendant species consist of pairs of individuals - an observation that is conspicuous because of the close proximity of individuals of these foraging pairs. Greenberg and Gradwohl (1980) have described a similar situation for Canada Warblers in Panama. Whether these are male-female pairs, and whether these shortlived species have permanent pair bonds is unknown and would be an unusual and unexpected finding.

The species composition of a given flock is predictable from knowledge of the habitat type (Fig. 1). My impression is that, although there is some turnover of individuals as the flock progresses through the smaller, individual territories of some species (e.g., Western Flycatcher, Wilson's Warbler, Rufous-capped Warbler, Painted Redstart), the majority of participants occupy the entire range traversed by the flock. If true, this would be similar to the situation described in Peru by Munn and Terborgh (1979), where 12 species were found to defend a common territorial boundary. Hence, the species composition is very stable and is undoubtedly the reason that I could record one-time flock compositions and observe such predictable patterns in composition over a habitat gradient; the flocks are not haphazard groupings that vary widely in composition through space or time. Systematic study of banded individuals is needed to establish the nature of any compositional changes associated with particular flocks, if such changes occur at all.

Regularity in the absolute abundances of species seems to be the proximate result of intraspecific aggression. Such aggression appears to be common in most mixed-species flocks (Bock 1969, Morse 1970, Greig-Smith 1978, Munn and Terborgh 1979, Wiley 1980, Powell 1985). When members of a flock meet individuals of another flock, aggressive encounters occur between individuals of the same species. Some of these encounters result in individual birds grappling to the ground, as described for Bushtits by Ervin (1977). While limits on the number of individuals per species seems to be set by interference competition (through such intraspecific aggression), my observations of interspecific aggression were much rarer, suggesting that the number of species in a flock may be set proximately by habitat structure (Fig. 1) and/or exploitative competition (Croxall 1976, Powell 1979), rather than interspecific aggression.

Seasonal changes in flock composition accompanied the departure of migratory species in April or May. During the breeding season in May and June, cohesive flocks probably no longer formed on a daily basis because flocking and breeding activities are generally incompatible (Sedgwick 1949, McClure 1967, Morse 1970, Chipley 1977, Powell 1985). By mid-July, the resident insectivores (Table 3 ) foraged in mixed-species flocks that contained about as many individuals as winter flocks, and there were five to 10 individuals belonging to species that averaged two to three individuals in winter.

From the standpoint of avian community ecology, western Mexico appears to be unique not only because of the unusually large geographic and habitat overlap among temperate migrant bird species (Hutto 1985), and the comparatively high densities of migrants in many habitats (Hutto 1980 ), but because of its unusually large, diverse, and migrant-rich mixed-species flocks as well.

\section{ACKNOWLEDGMENTS}

I would like to dedicate this paper to the memory of Harry Bell, who offered me both stimulation through his work on Australian and New Guinean flocks, and 
encouragement. Financial support during various phases of this study was provided by the University of California, World Wildlife Fund-U.S., the Smithsonian Institution, and the University of Montana. Research facilities at the La Michilia Biosphere Reserve and the Estación de Biología Chamela were provided by the Instituto de Ecologia and the Universidad Nacional Autónoma de México, respectively. I extend special thanks to Jorge Nocedal for suggesting study at La Michilia, and to Sonia Gallina and Steve Bullock for logistic support. I also thank Paul Hendricks and Sandra Pletschet for field assistance at La Michilia, and Jared Diamond for helpful comments on the manuscript.

\section{LITERATURE CITED}

Austin, G. T., AND E. L. Smith. 1972. Winter foraging ecology of mixed insectivorous bird flocks in oak woodland in southern Arizona. Condor 74: $17-24$.

BeLL, H. L. 1980. Composition and seasonality of mixed-species feeding flocks of insectivorous birds in the Australian Capital Territory. Emu 80:227232.

Bock, C. E. 1969. Intra vs. interspecific aggression in Pigmy Nuthatch flocks. Ecology 50:903-905.

BrowN, J. H. 1973. Species diversity of seed-eating desert rodents in sand dune habitats. Ecology 54: 775-787.

Buskirk, W. H., G.V.N. Powell, J. F. WitTenberger, R. E. BuSKIRK, AND T. U. Powell. 1972. Interspecific bird flocks in tropical highland Panama. Auk 89:612-624.

ChIPley, R. M. 1977. The impact of wintering migrant wood warblers on resident insectivorous passerines in a subtropical Colombian oak woods. Living Bird 15:119-141.

Cody, M. L. 1974. Competition and the structure of bird communities. Monogr. Popul. Biol. 7:1-318.

Croxall, J. P. 1976. The composition and behavior of some mixed-species bird flocks in Sarawak. Ibis 118:333-346.

DAvis, D. E. 1946. A seasonal analysis of mixed flocks of birds in Brazil. Ecology 27:168-181.

DesGranges, J. L., and P. R. Grant. 1980. Migrant hummingbirds' accommodation into tropical communities, p. 395-409. In A. Keast and E. S. Morton [eds.], Migrant birds in the Neotropics. Smithsonian Institution Press, Washington, DC.

EATON, S. W. 1953. Wood warblers wintering in Cuba. Wilson Bull. 65:169-174.

Ervin, S. 1977. Flock size, composition, and behavior in a population of Bushtits (Psaltriparus minimus). Bird-Banding 48:97-109.

Feinsinger, P. 1980. Asynchronous migration patterns and the coexistence of tropical hummingbirds, p. 411-419. In A. Keast and E. S. Morton [eds.], Migrant birds in the Neotropics. Smithsonian Institution Press, Washington, DC.

GibB, J. A. 1960. Populations of tits and goldcrests and their food supply in pine plantations. Ibis 102: 163-208.

Gradwohl, J., AND R. Greenberg. 1980. The for- mation of antwren flocks on Barro Colorado Island, Panama. Auk 97:385-395.

Greenberg, R., and J. Gradwohl. 1980. Observations of paired Canada Warblers Wilsonia canadensis during migration in Panama. Ibis 122:509 512.

Greig-SMITH, P. W. 1978. The formation, structure and function of mixed-species insectivorous bird flocks in west African savanna woodland. Ibis 120: 284-297.

Hartigan, J. 1981. Cluster analysis of variables, p. 448-455. In W. J. Dixon [chief ed.], BMDP statistical software. Univ. California Press, Berkeley.

Herrera, C. M. 1978. Ecological correlates of residence and non-residence in a Mediterranean passerine bird community. J. Anim. Ecol. 47:871890.

Herrera, C. M. 1979. Ecological aspects of heterospecific flock formation in a Mediterranean passerine bird community. Oikos 33:85-96.

Hutro, R. L. 1980 . Winter habitat distribution of migratory land birds in western Mexico, with special reference to small, foliage-gleaning insectivores, p. 181-203. In A. Keast and E. S. Morton [eds.], Migrant birds in the Neotropics. Smithsonian Institution Press, Washington, DC.

Hurto, R. L. 1981 . Temporal patterns of foraging activity in some wood warblers in relation to the availability of insect prey. Behav. Ecol. Sociobiol. 9:195-198.

HutTo, R. L. 1985. Habitat selection by nonbreeding, migratory landbirds, p. 455-476. In M. L. Cody [ed.], Habitat selection in birds. Academic Press, Orlando, FL.

KARR, J. R. 1976. On the relative abundance of migrants from the north temperate zone in tropical habitats. Wilson Bull. 88:433-458.

MACARThUR, R. H. 1972 . Geographical ecology. Harper and Row, New York.

MacDonald, D. W., AND D. G. Henderson. 1977. Aspects of the behaviour and ecology of mixedspecies bird flocks in Kashmir. Ibis 119:481-491.

MCCluRe, H. E. 1967. The composition of mixed species flocks in lowland and sub-montane forests of Malaya. Wilson Bull. 79:130-154.

MoRsE, D. H. 1970. Ecological aspects of some mixedspecies foraging flocks of birds. Ecol. Monogr. 40: 119-168.

MOYNIHAN, M. 1962. The organization and probable evolution of some mixed species flocks of Neotropical birds. Smithson. Misc. Collect. 143:1-140.

MOYNIHAN, M. 1979. Geographic variation in social behavior and in adaptations to competition among Andean birds. Publ. Nuttall Ornithol. Club 18:1162.

Munn, C. A., AND J. W. Terborgh. 1979. Multispecies territoriality in Neotropical foraging flocks. Condor 81:338-347.

Pesman, M. W. 1962. Meet flora Mexicana. Dale King, Publ., Globe, AZ.

Powell, G.V.N. 1979. Structure and dynamics of interspecific flocks in a Neotropical mid-elevation forest. Auk 96:375-390.

Powell, G.V.N. 1980. Migrant participation in Neo- 
tropical mixed species flocks, p. 477-483. In A. Keast and E. S. Morton [eds.], Migrant birds in the Neotropics. Smithsonian Institution Press, Washington, DC.

Powell, G.V.N. 1985. Sociobiology and the adaptive significance of interspecific foraging flocks in the Neotropics. Ornith. Monogr. No. 36, American Ornithologists' Union, Washington, DC.

RAND, A. L. 1954. Social feeding behavior of birds. Fieldiana: Zoology 36:1-71.

SEDGWICK, E. H. 1949. Mixed associations of small birds in the south-west of western Australia. Emu 49:9-13.

APPENDIX 1. Geographic locations of flocks that were observed in western Mexico. The numbers correspond with flock numbers given in Tables 1 and 3, and Figure 1.

Tropical evergreen forest. I have included mangrove, plantation, second growth, and tropical evergreen forest habitats under this lowland (sea level to $10 \mathrm{~m}$ ) category (see Hutto [1980] for more complete descriptions of these habitat types). In all cases, the flocks generally moved along the disturbed edges or canopies of these habitats.

Flock 1 (4/2/75)-Estero del Pozo, San Blas, Nayarit.

Flock $2(23 / 2 / 76)-2 \mathrm{~km}$ east of Barra de Navidad, Jalisco.

Flock $3(11 / 2 / 76)$, Flock $10(3 / 2 / 75)-2 \mathrm{~km}$ north of Matanchen, Nayarit.

Flock $4(31 / 1 / 75)$, Flock $5(2 / 2 / 75)$, Flock $8(28 / 1 /$ 76), Flock $9(7 / 2 / 76)$-plantation and second growth sites $1 \mathrm{~km}$ south of San Blas, Nayarit.

Flock 6(14/2/75), Flock 7 (6/2/76)-evergreen forest edge $8 \mathrm{~km}$ east of San Blas, Nayarit.

Tropical deciduous forest. These sites included the short tree habitats just below the oak woodlands in elevation (sea level to $1,500 \mathrm{~m}$ ), and were dominated by plants in the genera Acacia, Bombax, Bursera, Caesalpinia, Ficus, and Tabebuia.

Flock $11(19 / 1 / 76)-135 \mathrm{~km}$ northwest of Mazatlan, Sinaloa.

Flock $12(4 / 3 / 75)-1 \mathrm{~km}$ south of Colima, Colima.

Flock $13(25 / 2 / 75)-70 \mathrm{~km}$ south of Barra de Navidad, Nayarit.

Flock 14(26/2/75) $-20 \mathrm{~km}$ south of Colima, Colima.

Flock $15(24 / 2 / 75)-240 \mathrm{~km}$ southwest of Guadalajara, Jalisco.

Flock $16(18 / 1 / 75)-10 \mathrm{~km}$ west of El Palmito, Sinaloa.

Flock $17(24 / 2 / 76)-10 \mathrm{~km}$ southeast of Chamela, Jalisco.

Oak woodland. These habitats consisted mostly of oaks (Quercus spp.), were rarely taller than $10 \mathrm{~m}$ in canopy height, and occurred from 1,500 to $2,200 \mathrm{~m}$.
SHORT, L. L., JR. 1961. Interspecies flocking of birds of montane forests in Oaxaca, Mexico. Wilson Bull. 73:341-347.

SINCLAIR, A.R.E. 1978. Factors affecting the food supply and breeding season of resident birds and movements of Palaearctic migrants in a tropical African savannah. Ibis 120:480-497.

WILEY, R. H. 1980. Multispecies antbird societies in lowland forests of Suriname and Ecuador: stable membership and foraging differences. J. Zool. (Lond.) 191:127-145.

Willis, E. O. 1966. The role of migrant birds at swarms of army ants. Living Bird 5:187-231.

APPENDIX I. Continued.

Flock $18(23 / 2 / 75)-20 \mathrm{~km}$ south of Guadalajara, Jalisco.

Flock $19(24 / 2 / 75)-100 \mathrm{~km}$ southwest of Guadalajara, Jalisco.

Flock $20(8 / 3 / 76)$, Flock $38(24 / 7 / 75)-40 \mathrm{~km}$ south of Tepic, Nayarit.

Flock $21(13 / 2 / 76)-35 \mathrm{~km}$ southeast of Tepic, Nayarit.

Pine-oak woodland. These woodlands were generally composed of a diverse mixture of pines (Pinus spp.), oaks (Quercus spp.), and occasionally madrones ( $A r-$ butus sp.), all of which stood $15 \mathrm{~m}$ high, on average (elevation range was 2,000 to $3,000 \mathrm{~m}$ ).

Flock 22 (9/3/75), Flock $23(29 / 2 / 76)$, Flock 39 (23/ $7 / 75)-31 \mathrm{~km}$ west of Morelia, Michoacán.

Flock $24(5 / 3 / 75)$, Flock $40(18 / 7 / 75)-10 \mathrm{~km}$ south of Carapan, Michoacán.

Flock $25(19 / 1 / 75)-1 \mathrm{~km}$ west of El Palmito, Sinaloa.

Flock $26(19 / 2 / 76)-50 \mathrm{~km}$ south of Puerto Vallarta, Jalisco.

Flock 27 (1/3/75), Flock 28 (1/3/75), Flock 29 (28/ 2/75)-Volcan de Fuego, Jalisco.

Flock 30 (10/3/75), Flock 31 (27/2/76), Flock 41 (20/ $7 / 75)-44 \mathrm{~km}$ east of Uruapan, Michoacán.

Flock $32(6 / 3 / 75)$, Flock $42(21 / 7 / 75)-5 \mathrm{~km}$ south of Patzcuaro, Michoacán.

Boreal forest. These included the high elevation $(>3,000$ m) pine-fir forests composed largely of Pinus pseudostrobus, Quercus laurina, and Abies religiosa.

Flock 33 (27/2/75), Flock 34 (27/2/75)-Volcan de Fuego, Jalisco.

Flock $35(7 / 3 / 75)$, Flock $36(8 / 3 / 75)$, Flock 43 (22/ $7 / 75)-58 \mathrm{~km}$ southeast of Morelia, Michoacán.

Flock 37 (8/3/75) - $28 \mathrm{~km}$ west of Mexico City, Distrito Federal. 
APPENDIX II. Common and scientific names of birds mentioned in the text.

\begin{tabular}{|c|c|}
\hline Common name & Scientific name \\
\hline Acorn Woodpecker & Melanerpes formicivorus \\
\hline $\begin{array}{l}\text { Yellow-bellied Sap- } \\
\text { sucker }\end{array}$ & Sphyrapicus varius \\
\hline $\begin{array}{l}\text { Ladder-backed Wood- } \\
\text { pecker }\end{array}$ & Picoides scalaris \\
\hline Hairy Woodpecker & Picoides villosus \\
\hline $\begin{array}{l}\text { Strickland's Wood- } \\
\text { pecker }\end{array}$ & Picoides stricklandi \\
\hline Northern Flicker & Colaptes auratus \\
\hline $\begin{array}{l}\text { White-striped Wood- } \\
\text { creeper }\end{array}$ & $\begin{array}{l}\text { Lepidocolaptes leucogas- } \\
\text { ter }\end{array}$ \\
\hline Tufted Flycatcher & Mitrephanes phaeocercus \\
\hline Greater Pewee & Contopus pertinax \\
\hline Pine Flycatcher & Empidonax affinis \\
\hline Empidonax sp. & Empidonax sp. \\
\hline Ash-throated Flycatcher & Myiarchus cinerascens \\
\hline Mexican Chickadee & Parus sclateri \\
\hline Bridled Titmouse & Parus wollweberi \\
\hline Bushtit & Psaltriparus minimus \\
\hline $\begin{array}{l}\text { White-breasted Nut- } \\
\text { hatch }\end{array}$ & Sitta carolinensis \\
\hline Brown Creeper & Certhia americana \\
\hline Gray-barred Wren & $\begin{array}{l}\text { Campylorhynchus mega- } \\
\text { lopterus }\end{array}$ \\
\hline pot & Campylorhynchus gularis \\
\hline $\begin{array}{l}\text { Golden-crowned King- } \\
\text { let }\end{array}$ & Regulus satrapa \\
\hline Ruby-crowned Kinglet & Regulus calendula \\
\hline Gnatcatcher & Polioptila caerulea \\
\hline Solita & Vireo solitarius \\
\hline & Vireo \\
\hline War & Vireo \\
\hline $\begin{array}{l}\text { Orange-crowned War- } \\
\text { bler }\end{array}$ & Vermivora celata \\
\hline Nash & Vermivor \\
\hline Virgi & Vermivora virginiae \\
\hline Tropical Parula & Parula pitiayumi \\
\hline $\begin{array}{l}\text { Crescent-chested War- } \\
\text { bler }\end{array}$ & Parula superciliosa \\
\hline Yellow-rumped Warbler & Dendroica coronata \\
\hline $\begin{array}{l}\text { Black-throated Gray } \\
\text { Warbler }\end{array}$ & Dendroica nigrescens \\
\hline Townsend's Warbler & Dendroica townsendi \\
\hline Hermit Warbler & Dendroica occidentalis \\
\hline Grace's Warbler & Dendroica graciae \\
\hline $\begin{array}{l}\text { Black-and-white War- } \\
\text { bler }\end{array}$ & Mniotilta varia \\
\hline Wilson's Warbler & Wilsonia pusilla \\
\hline & Cardellina rubrifrons \\
\hline & Ergaticus ruber \\
\hline Painted Redstart & Myioborus pictus \\
\hline Slate-throated Redstart & Myioborus miniatus \\
\hline Rufous-capped Warbler & Basileuterus rufifrons \\
\hline Golden-browed Warbler & Basileuterus belli \\
\hline Olive Warbler & Peucedramus taeniatus \\
\hline Hepatic Tanager & Piranga flava \\
\hline Red-headed Tanager & Piranga erythrocephala \\
\hline
\end{tabular}

